University of Nebraska - Lincoln

DigitalCommons@University of Nebraska - Lincoln

\title{
Specific Adaptation and Genetic Progress for Grain Yield in Great Plains Hard Winter Wheats from 1987 to 2010
}

\author{
Robert A. Graybosch \\ University of Nebraska-Lincoln, bob.graybosch@ars.usda.gov \\ C. James Peterson \\ Limagrain Cereal Seeds
}

Follow this and additional works at: https://digitalcommons.unl.edu/usdaarsfacpub

Part of the Agricultural Science Commons

\footnotetext{
Graybosch, Robert A. and Peterson, C. James, "Specific Adaptation and Genetic Progress for Grain Yield in Great Plains Hard Winter Wheats from 1987 to 2010" (2012). Publications from USDA-ARS / UNL Faculty. 916.

https://digitalcommons.unl.edu/usdaarsfacpub/916
}

This Article is brought to you for free and open access by the U.S. Department of Agriculture: Agricultural Research Service, Lincoln, Nebraska at DigitalCommons@University of Nebraska - Lincoln. It has been accepted for inclusion in Publications from USDA-ARS / UNL Faculty by an authorized administrator of DigitalCommons@University of Nebraska - Lincoln. 


\title{
Specific Adaptation and Genetic Progress for Grain Yield in Great Plains Hard Winter Wheats from 1987 to 2010
}

\author{
Robert A. Graybosch ${ }^{\star}$ and C. James Peterson
}

\begin{abstract}
A previous investigation, using region-wide data from Great Plains wheat (Triticum aestivum L.) breeding trials, indicated a possible plateau in the rate of genetically determined yield potential. Data from the same USDA-Agricultural Research Service (ARS) coordinated long-term regional performance nurseries was used to further examine the rate of genetic improvement of Great Plains winter wheats in specific agroecological or production zones over the time period 1987 to 2010 . The absolute grain yield of all entries and of the top five most productive entries increased in the majority of production zones over this time period. The relative rate of genetic improvement, obtained by comparing grain yields to those of the long-term control cultivar Kharkof, ranged from not significantly different from zero to $1.98 \% \mathrm{yr}^{-1}$. This rate of change, however, was statistically significant $(\alpha=0.05)$ in only two of the 12 zones evaluated. Variance components identified production zone and locations within production zone as being the largest sources of variation in grain yields. Variance due to either genotype or genotype $\times$ environmental factors remained both constant over the 24-yr time period and small, relative to the environmental variances. Genetic progress for enhanced wheat yield in the region might be limited by the magnitude of these environmental variances and by constraints arising from continuous evolution of pest and pathogen populations.
\end{abstract}

R.A. Graybosch, USDA-ARS, 137 Keim Hall, East Campus, University of Nebraska, Lincoln, NE 68583; C.J. Peterson, Limagrain Cereal Seeds, 2040 SE Frontage Rd, Ft. Collins, CO 80525. Received 05 Aug 2011. *Corresponding author (bob.graybosch@ars.usda.gov). Mention of firm names or trade products does not imply that they are endorsed or recommended by the USDA or the University of Nebraska over other firms or products not mentioned. USDA is an equal opportunity provider and employer.

Abbreviations: $5 \mathrm{MP}$, five most productive entries; ARS, Agricultural Research Service; NRPN, Northern Regional Performance Nursery; SRPN, Southern Regional Performance Nursery.

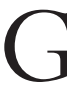
LOBAL POPUlation by the year 2050 likely will approach Jor exceed 10 billion people. To adequately feed this multitude, food production must increase by 50 to 70\% (Jaggard et al., 2010). In addition, caloric intake generally increases as nations develop economically and socially, placing additional demands on food production systems (Schneider et al., 2011). Rask and Rask (2011) noted that while per capita consumption of many grain crops decreases when incomes rise, wheat [Triticum aestivum L. and Triticum turgidum L. subsp. durum (Desf.) Husn.] consumption actually increases. Elevated atmospheric $\mathrm{CO}_{2}$ concentrations might induce increased productivity of C3 plants (Jaggard et al., 2010), but it is unlikely such enhancements will be large enough to meet the increased caloric demand. Improved varieties must be deployed to increase the innate potential of crop species to produce more calories per hectare. Unsettling, however, is the observation that for most cereal species, the observed rate of increase in genetically determined potential yields has been decreasing (Fischer and Edmeades, 2010).

Published in Crop Sci. 52:631-643 (2012).

doi: 10.2135/cropsci2011.08.0412

Published online 8 Dec. 2011.

(C) Crop Science Society of America | 5585 Guilford Rd., Madison, WI 53711 USA

All rights reserved. No part of this periodical may be reproduced or transmitted in any form or by any means, electronic or mechanical, including photocopying, recording, or any information storage and retrieval system, without permission in writing from the publisher. Permission for printing and for reprinting the material contained herein has been obtained by the publisher. 
The Great Plains Region of North America contains one of the world's largest concentrations of common and durum wheat production. Without increased productivity from wheat producers in this region, it is unlikely the ever-increasing food needs of the world's population will be satisfied. Recently, trends in genetic improvement for grain yield were evaluated for Great Plains common winter wheats using data from USDA-Agricultural Research Service (ARS) coordinated long-term regional performance trials (Graybosch and Peterson, 2010; USDA, 2011). Region-wide average grain yields, relative to the long-term check cultivar Kharkof, were used to demonstrate that over a $50 \mathrm{yr}$ period, the genetic potential for grain yield had increased at a rate of approximately $1 \% \mathrm{yr}^{-1}$. However, most of this increase in grain yield potential had been achieved by the late 1980s. Two trials were evaluated: the Southern Regional Performance Nursery (SRPN) and the Northern Regional Performance Nursery (NRPN). In the SRPN, no statistically significant increase in genetic potential for grain yield was observed for the time period 1984 to 2008 whereas in the NRPN, a modest rate of increase of $0.83 \% \mathrm{yr}^{-1}$ was observed but the goodness of fit of the calculated regression equation of relative grain yield to year was low $\left(r^{2}=0.23\right)$.

One potential drawback of the study of Graybosch and Peterson (2010) was the use of region-wide averages to determine relative grain yields of entries. The two nurseries used in the study cover wide geographic regions. The SRPN contains trials seeded from Texas north to include South Dakota and from Missouri to the eastern slopes of the Rocky Mountains. The NRPN is planted at locations from Kansas north to include Alberta, Canada, and from the Missouri River west to the Intermountain Region. Variances associated with genotype $\times$ environment effects on grain yield in the region are high, and they increased in the nursery trials steadily over the time period 1959 to 1984 (Peterson et al., 1989). High genotype $\times$ environment variances suggest that wheat breeders have focused more on breeding for specific adaptation than for adaptation to broad environments and geographic regions. According to Falconer (1960), "The existence of genotype-environment interaction may mean that the best genotype in one environment is not the best in another environment." Therefore, the use of regional averages could underestimate genetic progress because such results might obscure the true genetic potential for grain yield of the most highly adapted types in specific environments or locations. Graybosch and Peterson (2010) did attempt to address the issue of ill-adapted genotypes depressing some location means by also using data from the most productive entries and the five most productive entries (as determined again by regional averages). Such approaches might still suffer, however, from a lack of focus on specific production environments.

Alternative approaches to the use of regional averages would include examination of relative yield trends in specific locations, specific environments, or under specific production practices. In the Great Plains wheat production region, crop failures due to severe yearly weather events are common. Year-to-year and within-year variability in precipitation patterns is great. Therefore, year-to-year variation in grain yield at specific geographic locations not only is large but likely great enough to obscure any increases in relative grain yield due to genetic improvement. An alternative method would be to examine rates of genetic improvement within larger-scale homogeneous environments, in which each environment contains multiple testing sites. Using long-term data from the SRPN and NRPN, Peterson (1992) determined that testing sites in both trials could be assigned to one of several agro-ecological zones, designated intraregional production zones or areas of adaptation. Similarity of genotype performance among locations was used to cluster test sites and define six production zones within the SRPN and five such zones within the NRPN. The designated production zones (Peterson, 1992) correspond to recognized ecological adaptation zones for native vegetation in the Great Plains (Vogel et al., 2005).

The present investigation was undertaken to further examine recent trends in wheat breeding for grain yield in the Great Plains. First, variance components were estimated to determine whether the increase in genotype $\times$ environment variances in the nurseries over the time period 1959 to 1984, described by Peterson et al. (1989), has continued. Such a trend would indicate increased specific adaptation of Great Plains winter wheats. Second, trends in breeding line responses to environments were evaluated by examining of the stability of the long-term check Kharkof over time. Regression analysis (Eberhart and Russell, 1966) was used each year in each nursery to determine environmental stability of entries via correlation of genotype location performance to location means (USDA, 2011). A change in the relative stability parameter ( $\beta$-value from regression) of Kharkof over the years would indicate changes in the average response of entries to environment (Peterson et al., 1989). Finally, trends in genetic improvement for grain yield in Great Plains hard winter wheats were reexamined, again using regional performance data but with the focus of the present investigation being on trends within Peterson's (1992) production zones (areas of adaptation).

\section{MATERIALS AND METHODS}

All data were obtained from long-term records maintained by the USDA-ARS Grain, Forages and Biofuels Research Unit, Lincoln, NE. Data from the years 1987 to 2010 were used. Raw (field replication within locations) data no longer are available from years before 1987. Summarized annual regional reports of the SRPN and NRPN are available online (USDA, 2011). The SRPN, as of 2011, typically contains 45 to 50 entries, including controls, and is grown in replicated yield trials at 30 locations in Texas, New Mexico, Colorado, Oklahoma, Missouri, Kansas, Nebraska, Iowa, Wyoming, and South Dakota. All but five 
Table 1. Southern and Northern Regional Performance nurseries and assignment of locations to production zones.

\begin{tabular}{ll}
\hline \multicolumn{1}{c}{ Production zones $^{\dagger}$} & \multicolumn{1}{c}{ Locations included $^{\text {SRPN }} \begin{array}{l}\text { Southern Plains } \\
\text { Southern High Plains }\end{array}$} \\
$\begin{array}{l}\text { Central Plains } \\
\text { North Central Plains }\end{array}$ & Hays, KS; Hutchinson, KS; Wichita, KS; Salina, KS; Winfield, KS \\
Northern High Plains & Colby, KS; Burlington, CO; Akron, CO; Julesburg, CO; North Platte, NE; Sidney, NE; Archer, WY; Pine Bluffs, WY \\
Intermountain & Lind, WA; Aberdeen, ID; Farmington, NM; Fort Collins, CO; Alliance, NE \\
Irrigated Trials & Bushland, TX; Clovis, NM; Farmington, NM; Goodwell, OK; Fort Collins, CO \\
NRPN & \\
North Central Plains & Palmer, KS; Clay Center, NE; Lincoln, NE; North Platte, NE; Highmore, SD; Brookings, SD; Winner, SD; Ames, IA; \\
& Waseca, MN; St. Paul, MN \\
Northern High Plains & Goodland, KS; Sidney, NE; Alliance, NE; Archer, WY; Pine Bluffs, WY \\
Northern Plains & Hettinger, ND; Prosper, ND; Casselton, ND; Carrington, ND \\
Northwest Plains & Presho, SD; Pierre, SD; Williston, ND; Highmore, SD; Sidney, MT \\
Northwest & Lind, WA; Moccasin, MT; Bozeman, MT; Lethbridge, Alberta \\
\hline
\end{tabular}

†SRPN, Southern Regional Performance Nursery; NRPN, Northern Regional Performance Nursery.

locations are rainfed. Irrigated trials are planted at Clovis and Farmington, NM, Bushland, TX, Goodwell, OK, and Fort Collins, CO. The NRPN generally contains 30 to 35 entries and is grown at 21 sites in Kansas, Nebraska, Iowa, Wyoming, South Dakota, North Dakota, Minnesota, and Alberta, Canada. Only the Alberta site (Lethbridge) is irrigated. Plot size and seeding rates vary due to differences in local cooperator equipment and procedures. All locations seed the trials as randomized complete block designs with at least three replications. Pathogen control generally is not practiced. Typically, untreated seed is planted.

SAS version 9.1 (SAS Institute, 2008) and SigmaPlot version 11.0 (Systat Software, 2010) were used for statistical analyses. SAS PROC GLM (SAS Institute, 2008) was used to analyze variance contributed by the following main effects: production zone, location within production zone, and genotype. Interactions of genotype $\times$ production zone and genotype $\times$ location within production zone also were included in the model. Variance components (percent of total variance attributed to each main and interaction effect) were calculated using PROC VARCOMP (SAS Institute, 2008), method type 1. Regression coefficients ( $\beta$-values) from the stability analysis of Kharkof in each year of each nursery were obtained (USDA, 2011) and plotted against year of the trial using SigmaPlot version 11.0. SigmaPlot also was used to calculate the regression equation and significance thereof of the relationship of Kharkof $\beta$-values to year.

For each production zone (Peterson, 1992), mean grain yield was determined per year. Production zone per year combinations were excluded from the analysis if fewer than two locations were successfully harvested. In the SRPN, an additional analysis was conducted using the five irrigated sites as a distinct production environment. Locations within each production zone are listed in Table 1. Locations were assigned to zones (Peterson, 1992) based on principal factor analysis of phenotypic correlations of grain yield of genotypes among locations. Thus, locations were assigned to zones based not on geographic location but on similarities of genotypic adaptation. Hence, the irrigated and dryland trials at Bushland, TX, clustered within different zones even though they were planted at the same geographic location. In addition, the SRPN and NRPN production zones were established via independent trials and analyses with distinct entries.
Therefore, some sites present in both SRPN and NRPN (for example, Pierre, SD) are assigned to different zones in the two trials. Data were converted to relative values by expressing means as a percentage of the mean of Kharkof from the same production zone per year. Additional check varieties included each year in the nurseries were excluded from the analyses because they have changed over time.

Within each production zone, regression analysis was used to evaluate relationships between both average and relative (to Kharkof) grain yield and calendar year of nursery. Separate regression analyses were performed for each production zone using (i) all experimental lines and (ii) the five most productive entries (5MP). The slopes from regression equations were used to estimate genetic gain as percent (Kharkof) per year. Slopes with probability levels $<0.05$ were considered statistically significant.

\section{RESULTS AND DISCUSSION}

Average grain yields of the check cultivar Kharkof, all entries, and the 5MP are listed in Table 2. Grain yields of Kharkof in the SRPN ranged from a low of $1961 \mathrm{~kg} \mathrm{ha}^{-1}$ in the Southern High Plains zone to a high of $3770 \mathrm{~kg} \mathrm{ha}^{-1}$ in the Intermountain Zone. Two of the sites in the Intermountain Zone, Ft. Collins, CO, and Farmington, NM, are irrigated, contributing to the higher yield of Kharkof in this zone. Kharkof also is better adapted to NRPN production zones. With the exception of the irrigated trials and the Intermountain Zone, average grain yield of Kharkof in the NRPN production zones exceeded that of all remaining SRPN production zones (Table 2). In the SRPN, average yields of all entries and 5MP were highest in the irrigated trials and in the Intermountain zone. In the NRPN, highest average yields of Kharkof, all entries, and 5MP all were observed in the Northwest zone.

Variance components (Fig. 1) indicated the greatest source of variance for grain yield over the 24-yr period arose from environmental factors, either location within zones or zones themselves. Variances due to genetic factors, namely genotype, genotype $\times$ zone, or genotype $\times$ 
Table 2. Average grain yields $\left(\mathrm{kg} \mathrm{ha}^{-1}\right)$ for production zones of the Southern and Northern Regional Performance nurseries for the yrs 1987 through 2010.

\begin{tabular}{|c|c|c|c|c|c|c|}
\hline \multirow[b]{2}{*}{ Production zones $^{\dagger}$} & \multicolumn{2}{|c|}{ Kharkof } & \multicolumn{2}{|c|}{ All entries } & \multicolumn{2}{|c|}{ Top five entries } \\
\hline & Mean & SD & Mean & SD & Mean & SD \\
\hline \multicolumn{7}{|l|}{ SRPN } \\
\hline Southern Plains & 1964 & 423 & 3739 & 549 & 4234 & 602 \\
\hline Southern High Plains & 1961 & 668 & 2876 & 874 & 3355 & 944 \\
\hline Central Plains & 1980 & 654 & 3232 & 800 & 3774 & 794 \\
\hline North Central Plains & 2353 & 590 & 3682 & 715 & 4294 & 731 \\
\hline Northern High Plains & 2252 & 559 & 3192 & 889 & 3659 & 942 \\
\hline Intermountain & 3770 & 529 & 5051 & 989 & 6043 & 1239 \\
\hline Irrigated Trials & 3327 & 472 & 5145 & 718 & 5948 & 979 \\
\hline \multicolumn{7}{|l|}{ NRPN } \\
\hline North Central Plains & 2569 & 577 & 3594 & 796 & 4085 & 814 \\
\hline Northern High Plains & 2444 & 517 & 3131 & 840 & 3595 & 967 \\
\hline Northern Plains & 3100 & 880 & 3732 & 1135 & 4454 & 1240 \\
\hline Northwest Plains & 2435 & 608 & 3038 & 909 & 3500 & 924 \\
\hline Northwest & 3486 & 750 & 4613 & 1102 & 5190 & 1187 \\
\hline
\end{tabular}

'SRPN, Southern Regional Performance Nursery; NRPN, Northern Regional Performance Nursery.

location within zone interactions, were minor relative to environmental variance; together, these two components rarely contributed more than $10 \%$ of the total observed variance. Contrary to the observations of Peterson et al. (1989) for the time period 1959 to 1984, no significant relationships were observed when the relative magnitude of the variances was correlated with year of nursery (data not shown). For the time period 1987 to 2010, the relative amount of variance due to genotype $\times$ environmental interaction has remained constant.

The stability of Kharkof relative to all other nursery entries was examined by correlating $\beta$-values with year of nursery trial (Fig. 2). In both the SRPN and NRPN, there was a slight but statistically significant $(p<0.05$ in both nurseries) decline in Kharkof's $\beta$-values over the evaluated time period. Before 1995, Kharkof $\beta$-values generally ranged from 0.6 to 0.7 ; in the most recent $5 \mathrm{yr}$ analyzed, values generally were observed to range from 0.4 to 0.7 . This continues the trend observed by Peterson et al. (1989) for the time period 1959 to 1984. Peterson et al. (1989) suggested this trend arose due to newer cultivars having greater advantage over Kharkof in "favorable or nonlimiting environments." Evidently, some breeding progress has continued to be made in such environments because the relative slope from the regression of Kharkof mean response to environmental means has continued to decline (Fig. 2). Any increase, however, in the level of specific adaptation of materials from Great Plains wheat breeding programs has been slight. Otherwise, some change would have been observed in the relative magnitude of genotypic variance or one of the genotype $\times$ environment interaction terms (Fig. 1).

Average grain yields of Kharkof, all entries, and 5MP given by year of trial are presented for each production zone in Fig. 3, 4, 5, and 6. Year-to-year fluctuations in average grain yield within each production zone were large, again due to year-to-year variation of climate in the Great Plains. In the majority of the SRPN zones, there were no significant correlations between average grain yields of all entries and 5MP with year of trial over the 24-yr period (Table 3 ), although average grain yield of all entries and 5MP did significantly increase in the Central Plains and North Central Plains zones. In the NRPN, average grain yields significantly increased over time in the North Central Plains, Northern Plains, Northwest Plains, and the Northwest production zones; in the remaining zone, the regression of grain yield vs. year was significant for all entries and for $5 \mathrm{MP}$ at the $\alpha=0.1$ level but not the $\alpha=0.05$ level.

Grain yield relative to the check cultivar Kharkof significantly increased in only two production zones (Table 4); in the Southern High Plains of the SRPN and in the Northwest zone of the NRPN the slopes from regression of all entries did indicate increases of approximately $2 \%$ Kharkof grain yield $\mathrm{yr}^{-1}$. Identical results were obtained using either all nursery entries or the 5MP only. The remaining zones of both nurseries demonstrated no significant rate of change at the $\alpha=0.05$ level. In some zones, particularly in the NRPN (Table 3), significance was observed for all entries at the $\alpha=0.10$ level, with observed $\beta$-values indicating an increase of approximately $1 \%$ Kharkof grain yield $\mathrm{yr}^{-1}$. In each case, however, the goodness of fit $\left(r^{2}\right)$ for the regression equations was low, making it difficult for an objective observer to declare a continued positive rate of change. In addition, for all zones in which significant positive slopes were observed for all entries at the 0.10 probability level, 5MP demonstrated nonsignificant $(p>$ $0.10)$ relationships. This observation perhaps suggests that average performance of nursery entries has increased but the difference between the highest performers and Kharkof essentially has remained unchanged. 

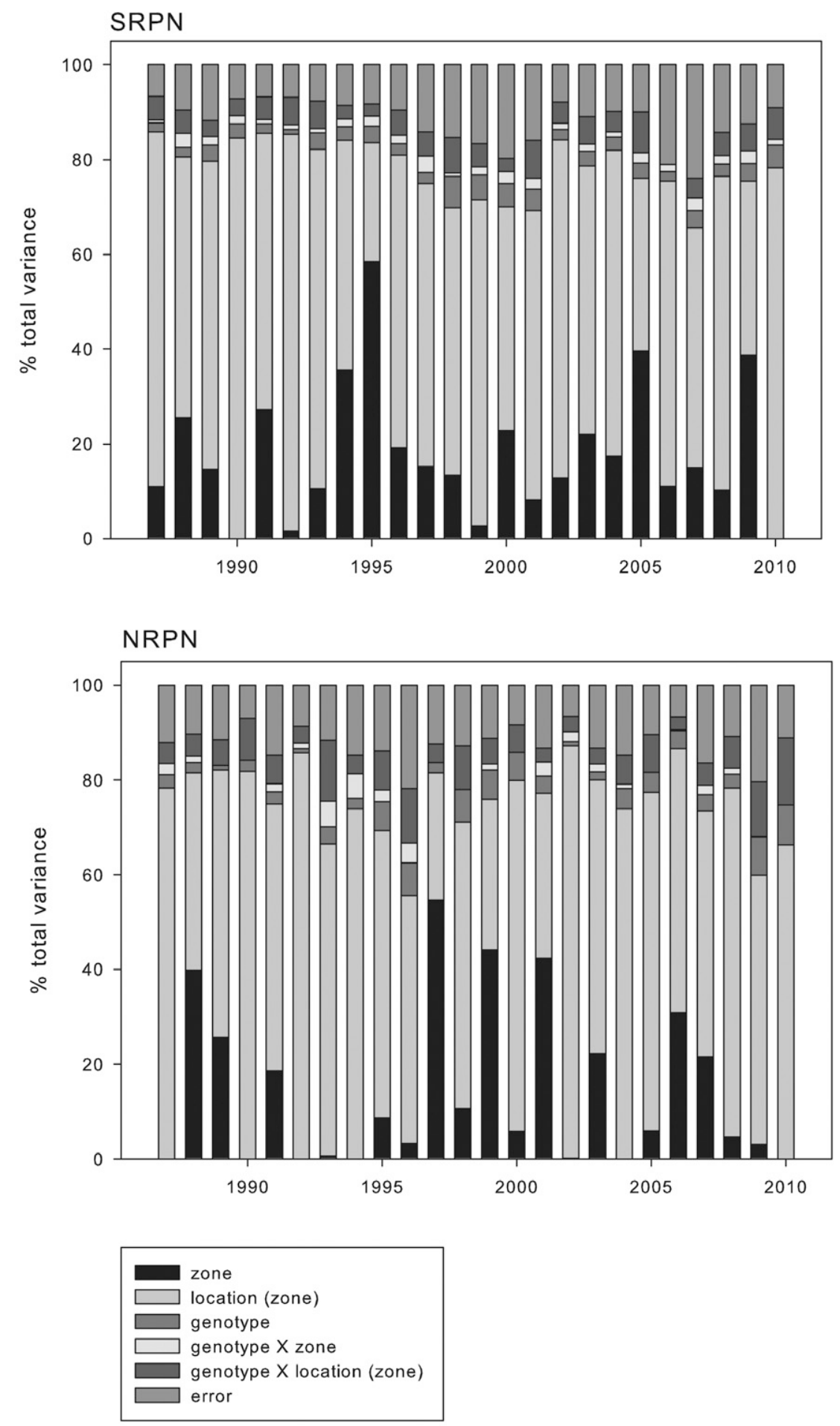

Figure 1. Components contributing to variance, expressed as percentage of the total variance, in grain yield of entries in the Southern Regional Performance Nursery (SRPN) and the Northern Regional Performance Nursery (NRPN) from 1987 to 2010.

The Southern High Plains zone demonstrated the lowest average genotype yield of any SRPN production zone; the Northwest zone had the highest average yield of NRPN Zones (Table 1). Kharkof, however, is relatively poorly adapted and late in maturity in the Southern High Plains, and the increase in relative grain yield in this region is perhaps related to drought years not allowing this cultivar enough time for proper maturity and grain fill. Peterson et al. (1989) noted that the major portion of genetic improvement in grain yield on SRPN and NRPN entries from 1959 to 1984 derived from improvement in favorable yield environments. The Northwest zone of the NRPN is the only zone in which this trend has continued to the present day. No significant increase in relative grain yield could be demonstrated over the time period 1987 to 2010 in other favorable zones, including the Intermountain 


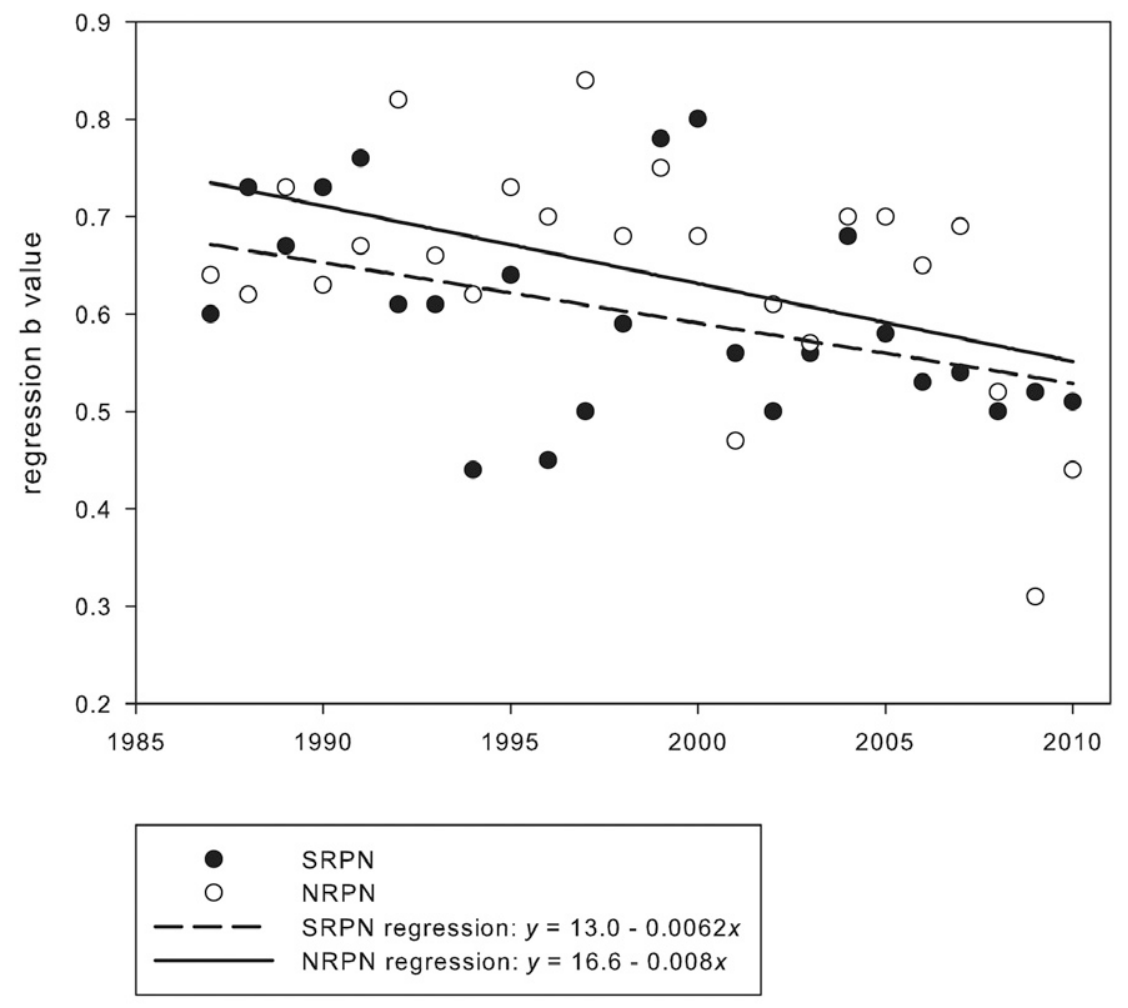

Figure 2. Coefficients (b values) from regression of Kharkof grain yields on mean grain yields at locations in the Southern Regional Performance Nursery (SRPN) and the Northern Regional Performance Nursery (NRPN) from 1987 to 2010.

zone and irrigated sites of the SRPN and the Northern Plains of the NRPN. In all other zones in which average grain yields of all entries and 5MP increased, average grain yield of Kharkof also increased (Fig. 3, 4, 5, and 6), and no significant correlations of relative grain yield vs. year were detected (Table 4). If the change in relative stability of yield of Kharkof demonstrated in Fig. 2 is due to increased genetic potential in favorable environments, it must be due to improved performance in specific locations and not over these larger-scale production zones.

The lack of increased genotype $\times$ environment interaction observed in both nurseries over time and the lack of a demonstrable increase in relative grain yield in the majority of production zones suggest that breeding programs have not increased specific adaptation of wheat in the region. It could be argued that a production zone still represents too broad of an area and relative yield and trends should be examined only at specific locations. However, an investigation parallel to the present one was conducted in which regression analysis was used to examine the relationships between relative grain yield and year in 11 specific locations of each nursery. No significant changes were observed in any of these locations over the $24 \mathrm{yr}$ time period (data not shown). Breeding for enhanced wheat grain yield in the Great Plains is limited by several aspects of the region. Variance components (Fig. 1) indicate that environmental effects are large, dwarfing the variances contributed by genetic factors. If only approximately
$10 \%$ of the yearly observed variances may be attributed to genetic factors (e.g., sum of the variances attributed to genotype and genotype $\times$ environment interactions), the opportunities to identify and select superior genotypes for grain yield are limited. Drought typically occurs in at least some portion of the Great Plains region each year. As noted by Ceccarelli (1994) "...yield improvements have been very elusive in marginal environments, to the point that the role of breeding for these environments is often questioned." Indeed, the entire Great Plains region represents a marginal environment. Perhaps, as Ceccarelli (1994) further suggested, “...one might argue whether breeding is in fact the best solution to increase agricultural production in marginal environments. Results obtained with fertilizer applications, or with irrigation are spectacular." Ceccarelli answered this question himself when he further noted, "The conclusions are inescapable; water and nutrient resources are often limited, and economic and environmental problems are likely to restrain their use." In other words, breeding to improve yield under marginal conditions, such as those predominating in the Great Plains, might not be the optimal approach to improving absolute grain yields, but it might be the only approach. In addition, constant and renewed pressure from pathogens (Kolmer et al., 2007; Graybosch and Peterson, 2010) alone justifies continued breeding work simply to maintain grain yields at current levels. 


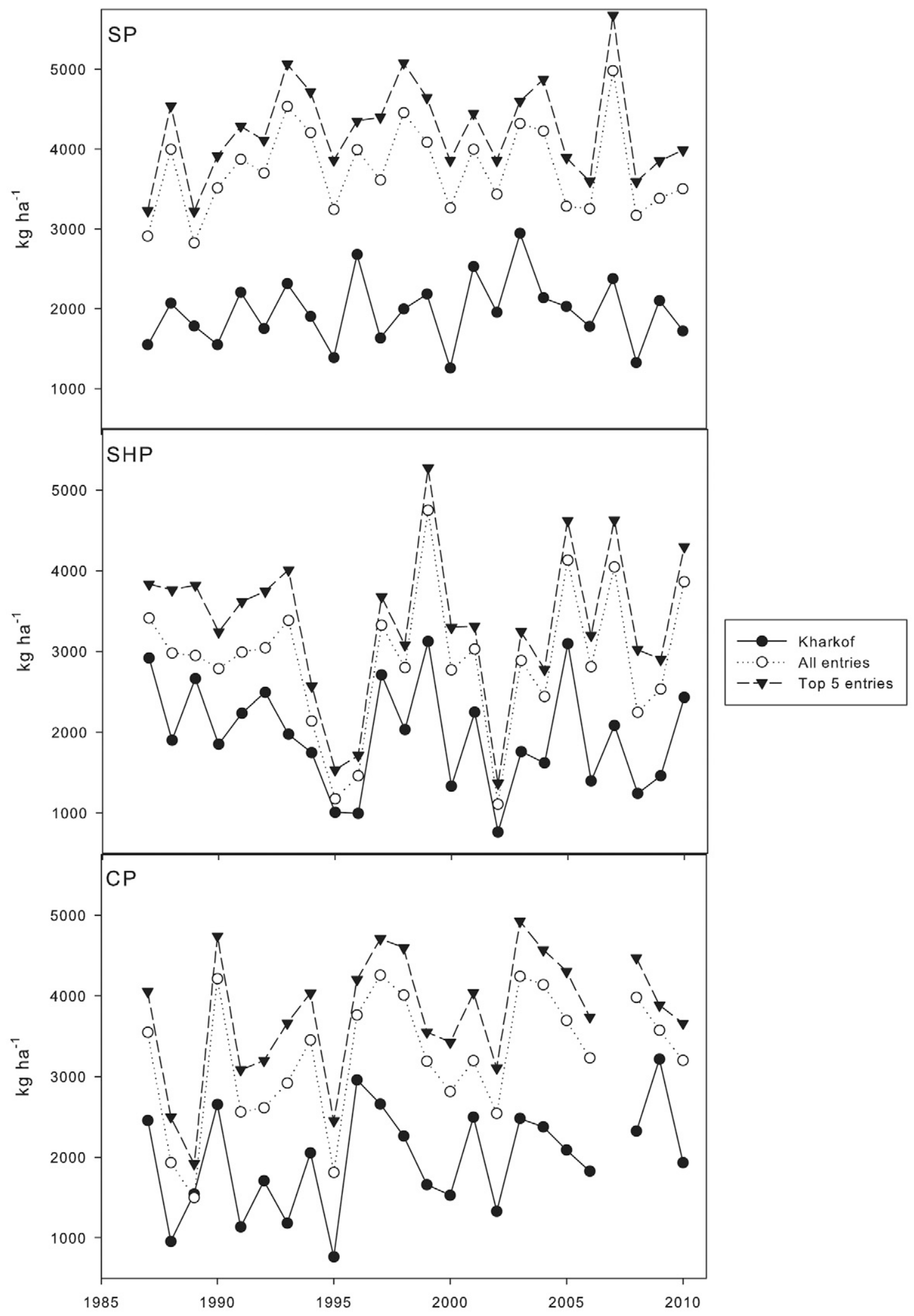

Figure 3. Average grain yield of Kharkof, all nursery entries, and the five most productive entries in three production zones of the Southern Regional Performance Nursery from 1987 to 2010. SP, Southern Plains; SHP, Southern High Plains; CP, Central Plains.

The trends observed in the current investigation confirm those of a previous study (Graybosch and Peterson, 2010) that suggested relative grain yields in the Great Plains had peaked in the late 1980 s and perhaps had reached a plateau. In the present study, little increase in relative grain yield was evident in the majority of the evaluated production zones or in the irrigated trials. The SRPN irrigated sites offer the most hospitable and stable 
NCP

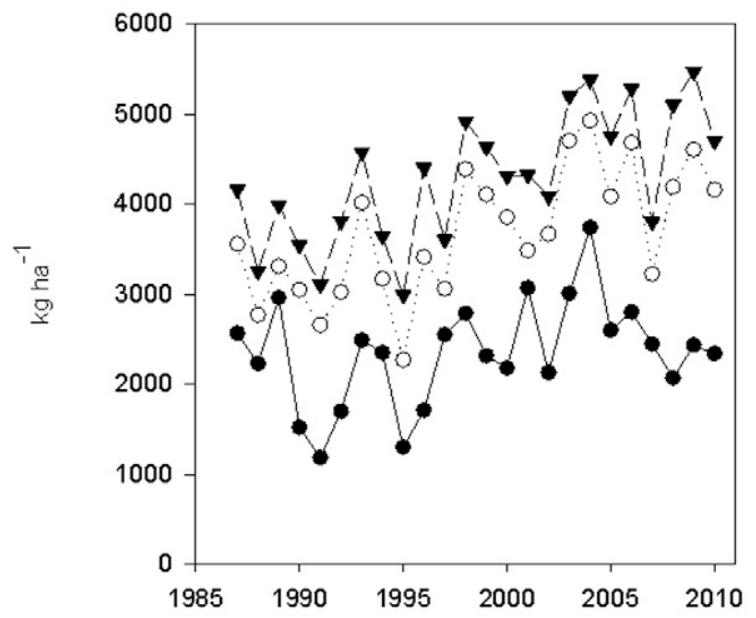

IRR

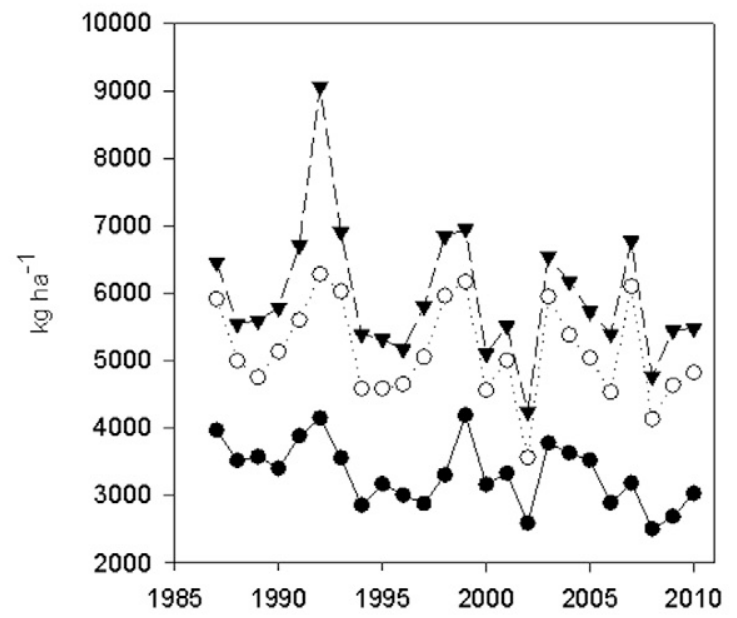

NHP

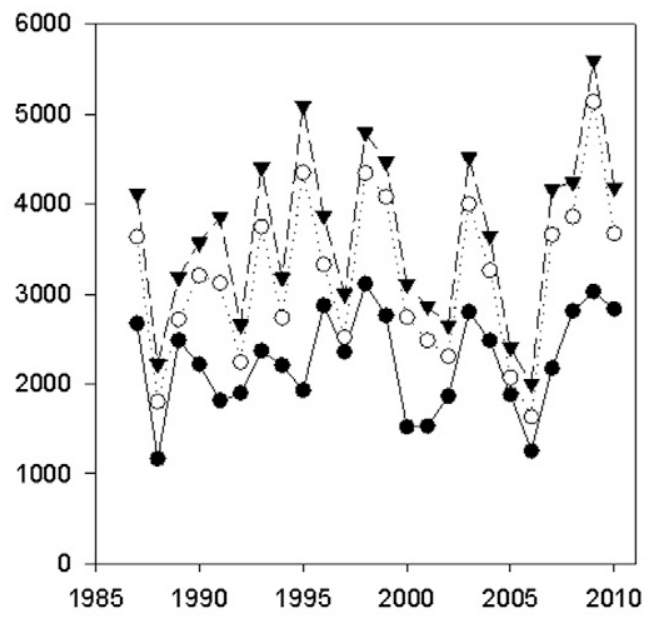

INT

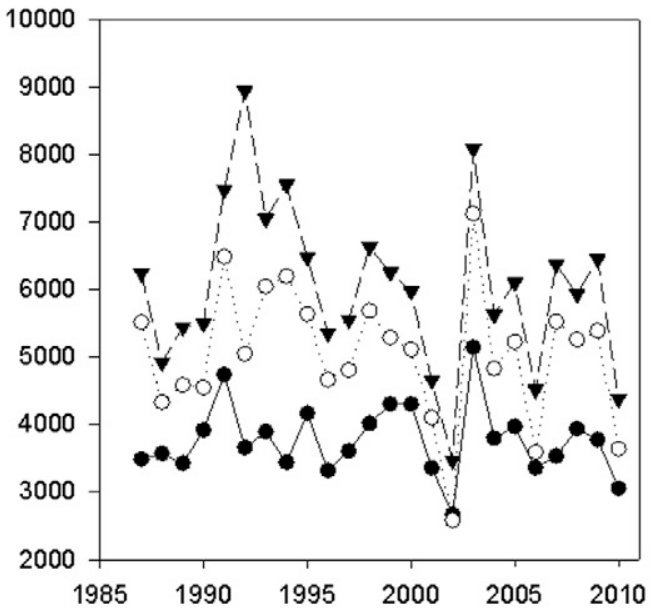

$$
\begin{array}{ll}
\longrightarrow & \text { Karkof } \\
\ldots . \cdots & \text { All entries } \\
-\rightarrow- & \text { Top } 5 \text { entries }
\end{array}
$$

Figure 4. Average grain yield of Kharkof, all nursery entries, and the five most productive entries in three production zones and irrigated sites of the Southern Regional Performance Nursery from 1987 to 2010. NCP, North Central Plains; NHP, Northern High Plains; IRR, irrigated trials; INT, Intermountain.

conditions for wheat production in the Great Plains, yet breeders have not been able to realize increases in relative performance of new breeding materials when compared to Kharkof.

An alternative explanation to the absence of genetic improvement could be that environmental constraints in the region prevent wheat cultivars from ever reaching their maximum potential or potential yield (Fischer and Edmeades, 2010) and that the present analysis and yearly nursery reports woefully underestimate the true genetic potential. The highest average yield of any production zone observed in this study occurred in the irrigated trials of 1992, in which the 5MP lines averaged $9065 \mathrm{~kg} \mathrm{ha}^{-1}$.
In the same trials, Kharkof averaged $4151 \mathrm{~kg} \mathrm{ha}^{-1}$. This translates to a relative yield of $218 \%$ of Kharkof. Systematic wheat breeding efforts began in the region in the early 1920s (Reitz and Heyne, 1944). Cultivars of the late 1950s had relative yields of approximately 100\% Kharkof (Peterson et al., 1989). This maximum observed relative of yield of $212 \%$ Kharkof would yield an estimated yearly increase of $2.24 \%$ Kharkof $\mathrm{yr}^{-1}$, nearly twice that of most other reported rates of genetic gain for yield in the region (Feyerherm et al., 1984; Cox et al., 1988; Donmez et al., 2001; Fufa et al., 2005). However, the argument is perhaps moot. In the Great Plains, wheat rarely is grown under optimal conditions, especially with regards to water availability. 


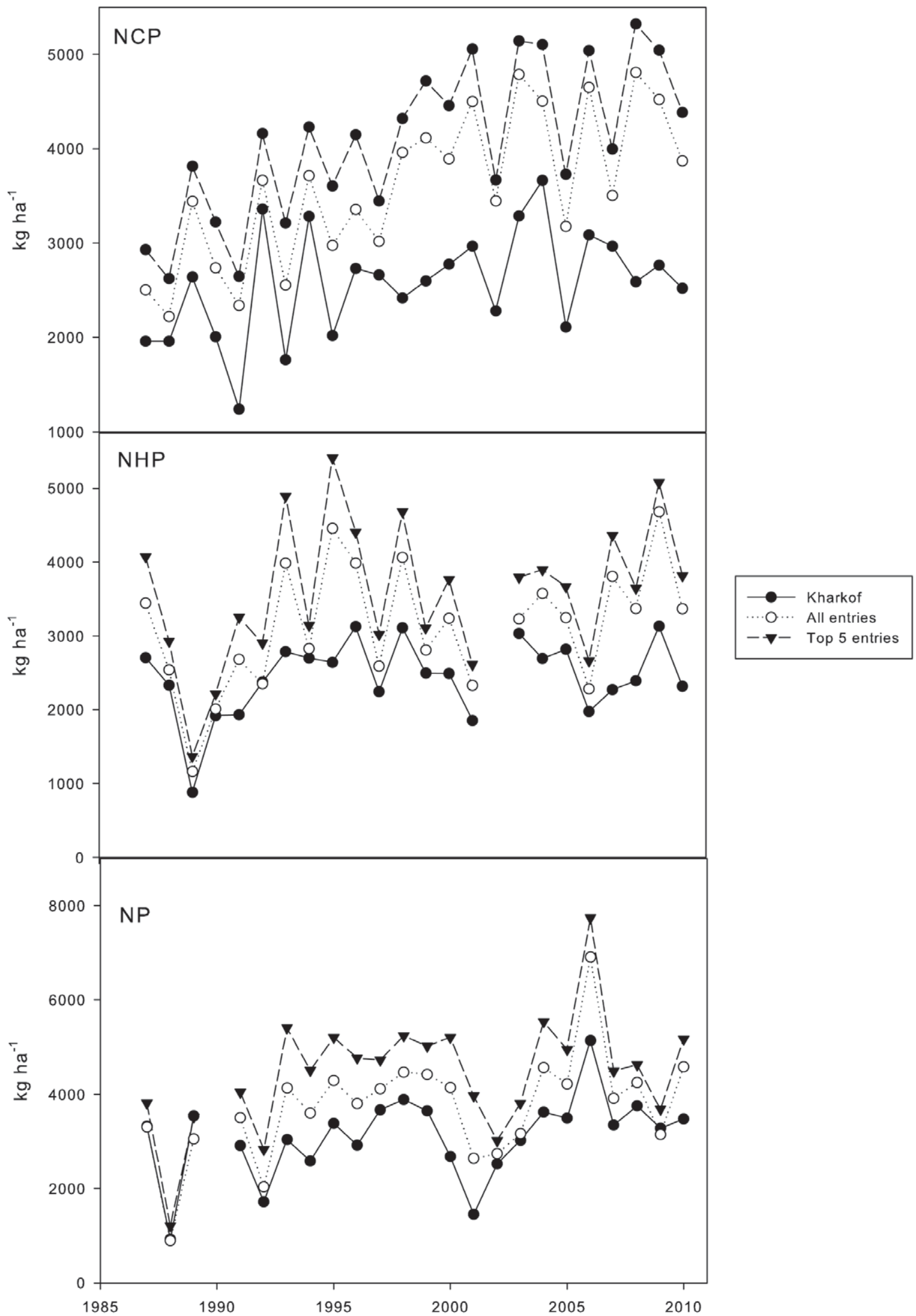

Figure 5. Average grain yield of Kharkof, all nursery entries, and the five most productive entries in three production zones of the Northern Regional Performance Nursery from 1987 to 2010. NCP, North Central Plains; NHP, Northern High Plains; NP, Northern Plains. 


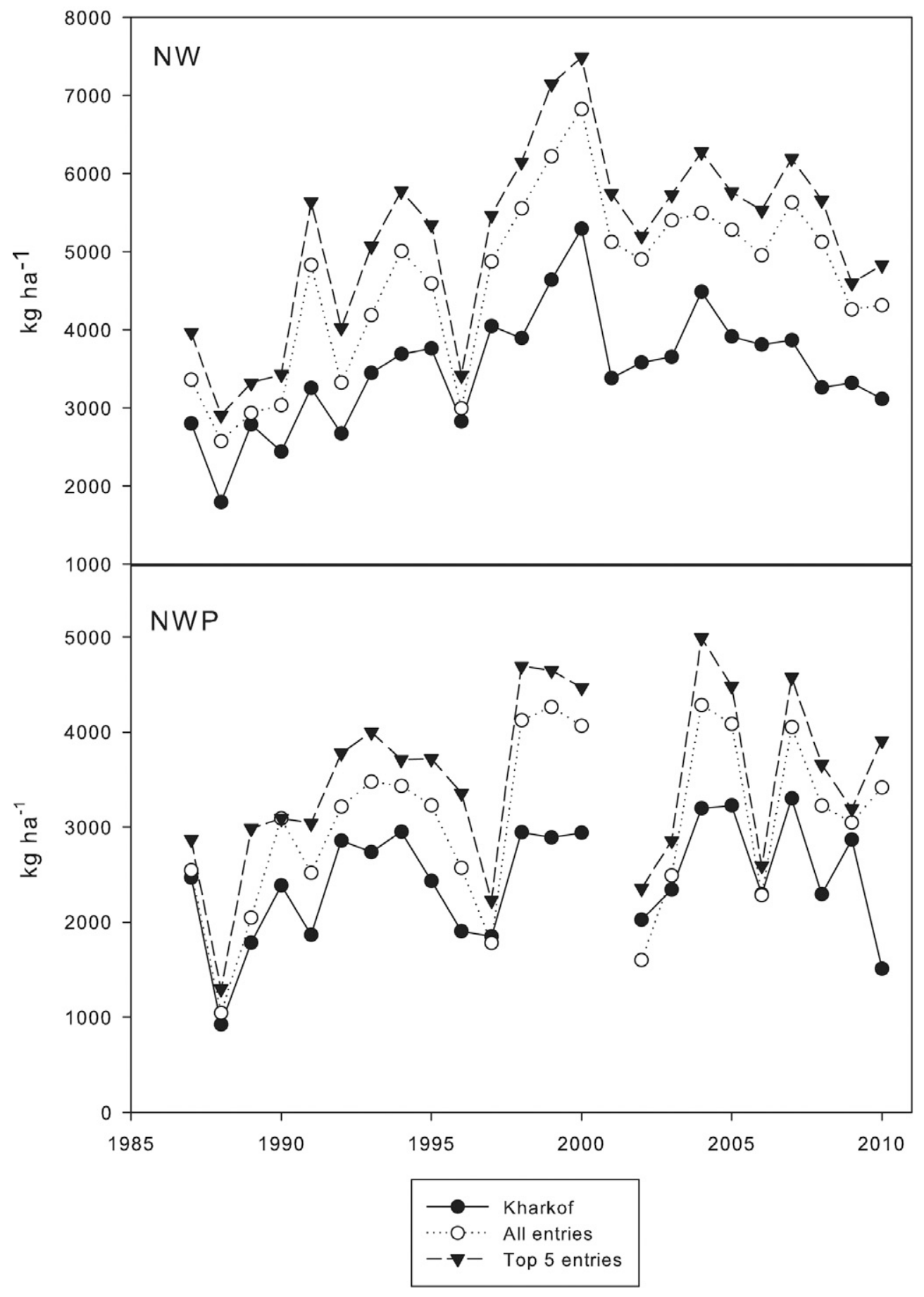

Figure 6. Average grain yield of Kharkof, all nursery entries, and the five most productive entries in two production zones of the Northern Regional Performance Nursery from 1987 to 2010. NW, Northwest; NWP, Northwest Plains.

The true rate of genetic gain indeed might be routinely underestimated; growers, however, are rarely able to capitalize on this true genetic potential. Average wheat grain yields (Fig. 7), expressed in kilograms harvested per hectare, of the five major Great Plains winter wheat producing states support this view. In only one state, Nebraska, did the regression of kilograms per hectare on year reveal a significant positive slope over the evaluated time period (data not shown). Should one, therefore, estimate genetic potential for yield under rare (optimal) conditions or under typical conditions, especially as growers rarely experience optimal conditions?

The present study also confirms previous observations (Graybosch and Peterson, 2010) that absolute but not relative grain yields of wheat have been increasing in the NRPN and, in addition, such a trend also was evident in the Central Plains and North Central Zone of the SRPN. Most cases of increased absolute yield over time occurred in zones spanning (North Central Zones) or north of (Northwest Zone, NRPN) the traditional borderline, 
Table 3. Regression analyses of average grain yields on year for wheat lines entered in the Southern and Northern Regional Performance nurseries by production zone for the time period 1987 to 2010.

\begin{tabular}{|c|c|c|c|c|c|c|c|c|}
\hline \multirow[b]{2}{*}{ Region and zone ${ }^{\dagger}$} & \multicolumn{4}{|c|}{ All entries } & \multicolumn{4}{|c|}{ Five most productive entries } \\
\hline & Slope & SE slope & $r^{2}$ & $p$ & Slope & SE slope & $r^{2}$ & $p$ \\
\hline \multicolumn{9}{|l|}{ SRPN } \\
\hline SP & 6.63 & 16.49 & 0.01 & 0.69 & 9.58 & 18.02 & 0.01 & 0.60 \\
\hline SHP & 11.73 & 27.54 & 0.01 & 0.67 & 4.11 & 29.88 & 0.01 & 0.89 \\
\hline $\mathrm{CP}$ & 57.42 & 22.03 & 0.25 & 0.02 & 54.42 & 22.20 & 0.23 & 0.02 \\
\hline NCP & 66.28 & 16.29 & 0.43 & $<0.01$ & 70.24 & 16.18 & 0.46 & $<0.01$ \\
\hline $\mathrm{NHP}$ & 27.61 & 26.15 & 0.05 & 0.30 & 23.18 & 27.98 & 0.03 & 0.42 \\
\hline ITM & -26.67 & 29.26 & 0.04 & 0.37 & -44.61 & 36.11 & 0.07 & 0.22 \\
\hline IRR & -26.76 & 20.89 & 0.07 & 0.21 & -39.95 & 28.25 & 0.08 & 0.17 \\
\hline \multicolumn{9}{|l|}{ NRPN } \\
\hline $\mathrm{NCP}$ & 82.63 & 16.31 & 0.54 & $<0.01$ & 84.24 & 16.73 & 0.54 & $<0.01$ \\
\hline $\mathrm{NHP}$ & 45.94 & 24.30 & 0.15 & 0.07 & 41.34 & 28.91 & 0.17 & 0.09 \\
\hline NP & 84.34 & 29.02 & 0.39 & 0.01 & 88.66 & 33.85 & 0.35 & 0.02 \\
\hline NWP & 80.66 & 26.86 & 0.35 & $<0.01$ & 84.60 & 27.44 & 0.36 & $<0.01$ \\
\hline NW & 108.73 & 28.33 & 0.46 & $<0.01$ & 103.96 & 33.29 & 0.36 & $<0.01$ \\
\hline
\end{tabular}

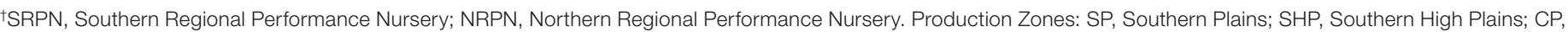

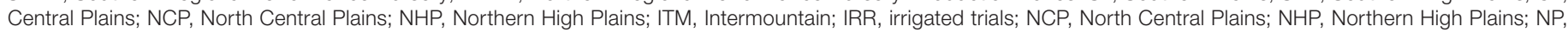
Northern Plains; NWP, Northwest Plains; NW, Northwest.

Table 4. Results of regression analyses of relative (to Kharkof) grain yields on year for wheat lines entered in the Southern and Northern Regional Performance nurseries by production zone for the time period 1987 to 2010.

\begin{tabular}{|c|c|c|c|c|c|c|c|c|}
\hline \multirow[b]{2}{*}{ Region and zone ${ }^{\dagger}$} & \multicolumn{4}{|c|}{ All entries } & \multicolumn{4}{|c|}{ Five most productive entries } \\
\hline & Slope & SE slope & $r^{2}$ & $p$ & Slope & SE slope & $r^{2}$ & $p$ \\
\hline \multicolumn{9}{|l|}{ SRPN } \\
\hline SP $\ddagger$ & -0.23 & 0.93 & 0.0029 & 0.80 & -0.15 & 1.16 & 0.0007 & 0.90 \\
\hline SHP & 1.98 & 0.67 & 0.2946 & $<0.01$ & 1.99 & 0.90 & 0.1906 & 0.04 \\
\hline $\mathrm{CP}$ & -0.72 & 1.20 & 0.02 & 0.56 & -1.75 & 1.63 & 0.0545 & 0.30 \\
\hline NCP & 0.57 & 0.92 & 0.0172 & 0.54 & 0.34 & 1.17 & 0.0038 & 0.78 \\
\hline NHP & 0.00 & 0.83 & 0.0000 & 0.99 & -0.38 & 0.97 & 0.0070 & 0.67 \\
\hline ITM & -0.61 & 0.52 & 0.0590 & 0.25 & -1.05 & 0.77 & 0.0779 & 0.19 \\
\hline IRR & 0.78 & 0.40 & 0.1485 & 0.06 & 0.69 & 0.54 & 0.0694 & 0.21 \\
\hline \multicolumn{9}{|l|}{ NRPN } \\
\hline NCP & 1.16 & 0.61 & 0.1396 & 0.07 & 0.91 & 0.69 & 0.0723 & 0.20 \\
\hline NHP & 0.98 & 0.54 & 0.1434 & 0.08 & 0.68 & 0.70 & 0.0447 & 0.35 \\
\hline NP & 0.97 & 0.52 & 0.2120 & 0.08 & 0.59 & 0.80 & 0.0397 & 0.48 \\
\hline NWP & 0.58 & 0.41 & 0.1039 & 0.18 & 0.09 & 0.42 & 0.0025 & 0.84 \\
\hline NW & 2.14 & 0.83 & 0.2810 & 0.02 & 1.98 & 1.02 & 0.1810 & 0.07 \\
\hline
\end{tabular}

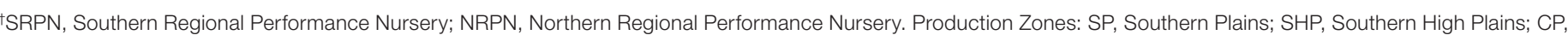

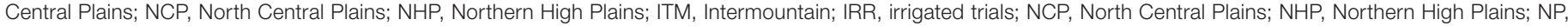
Northern Plains; NWP, Northwest Plains; NW, Northwest.

approximately $43^{\circ} \mathrm{N}$, of spring wheat versus winter wheat cultivation, again suggesting climatic factors rather than genetic factors were responsible. Over the past $24 \mathrm{yr}$, conditions in the region evidently have been more benign, allowing not only all entries in the trial to more closely attain their genetic potential for grain yield but conditioning greater production by the check cultivar Kharkof. As noted previously (Graybosch and Peterson, 2010) the increase in absolute grain yield of Kharkof over time could be due to climatic changes in the Great Plains (Easterling, 2002; Feng and $\mathrm{Hu}, 2004)$ resulting in increased moisture availability, milder winters with decreased winterkill in winter wheat plantings, and a longer growing season (Easterling, 2002; Feng and $\mathrm{Hu}, 2004$ ). Morgan et al.
(2008) and Lobell et al. (2011) have noted that recent and forecast climatic changes in the Northern Great Plains will actually enhance plant productivity. It remains doubtful, however, whether environmentally induced increases in wheat grain yields in the region will be sufficient, in the absence of increases in the rate of genetic improvement, to meet the world's demand for wheat.

\section{References}

Ceccarelli, S. 1994. Specific adaptation and breeding for marginal conditions. Euphytica 77:205-219.

Cox, T.S., R. Shroyer, L. Ben-Hui, R.G. Sears, and T.J. Martin. 1988. Genetic improvement in agronomic traits of hard red winter wheat cultivars from 1919 to 1987. Crop Sci. 28:756760 . 

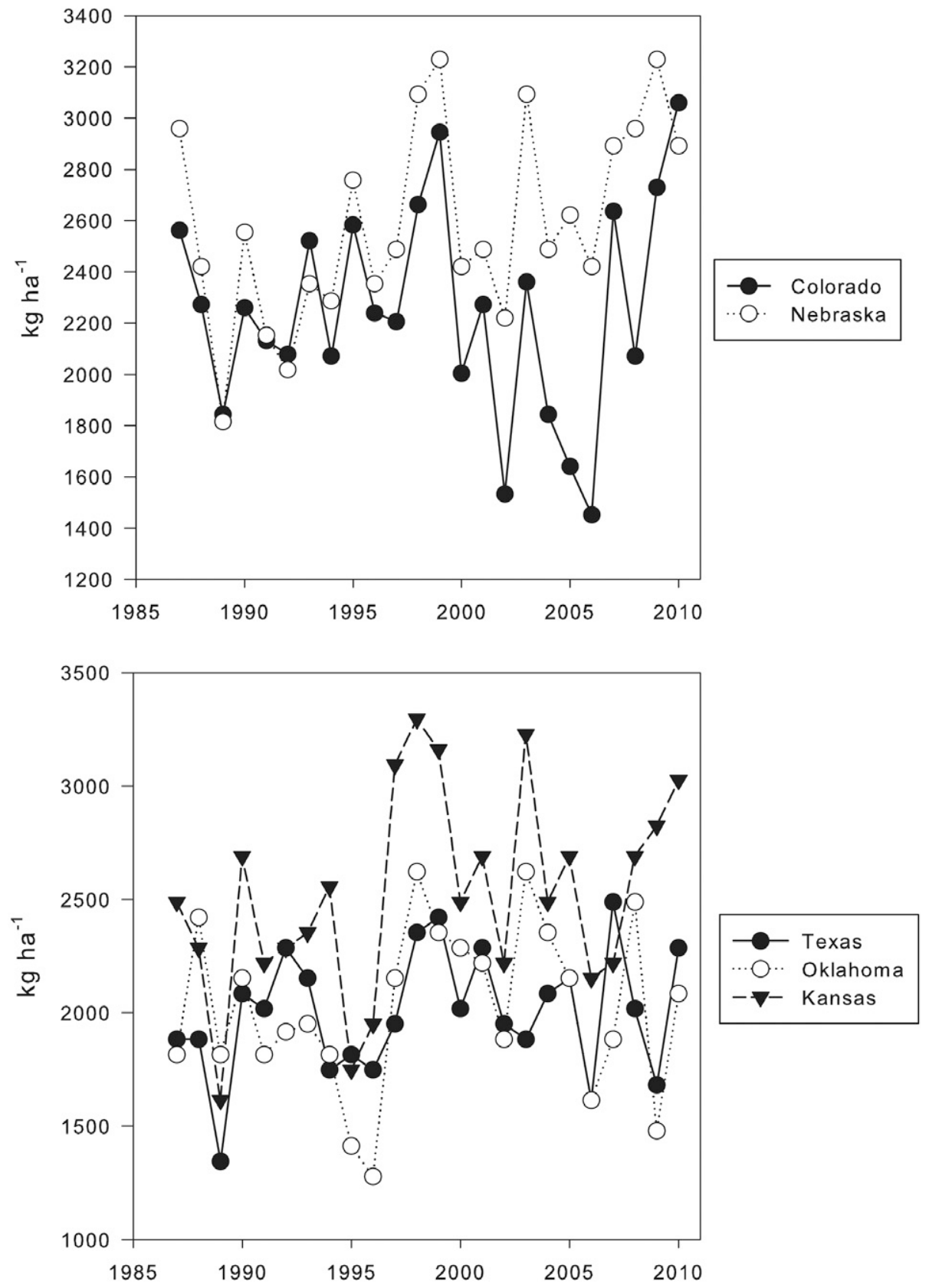

Figure 7. Average grain yield $\left(\mathrm{kg} \mathrm{ha}^{-1}\right)$ of wheat harvested in the five major Great Plains winter wheat producing states from 1985 to 2010 (USDA National Agricultural Statistics Service, 2011).

Donmez, E., R.G. Sears, J.P. Shroyer, and G.M. Paulsen. 2001. Genetic gain in yield attributes of winter wheat in the Great Plains. Crop Sci. 41:1412-1419.

Easterling, D.R. 2002. Recent changes in frost days and the frostfree season in the United States. Bull. Am. Meteorol. Soc. 83:1327-1332.

Eberhart, S.A., and W.A. Russell. 1966. Stability parameters for comparing varieties. Crop Sci. 6:36-40.

Falconer, D.S. 1960. Introduction to quantitative genetics. The Ronald Press Company, New York, NY.

Feng, S., and Q. Hu. 2004. Changes in agro-meteorological indicators in the contiguous United States: 1951-2000. Theor. Appl. Climatol. 78:247-264.

Feyerherm, A.M., G.M. Paulsen, and J.L. Sebaugh. 1984. Contribution of genetic improvement to recent wheat yield increases in the USA. Agron. J. 76:985-990.
Fischer, R.A., and G.O. Edmeades. 2010. Breeding and cereal yield progress. Crop Sci. 50:S85-S98.

Fufa, H., P.S. Baenziger, B.S. Beecher, R.A. Graybosch, K.M. Eskridge, and L.A. Nelson. 2005. Genetic improvement tends in agronomic performances and end-use quality characteristics among hard red winter wheat cultivars in Nebraska. Euphytica 144:187-198.

Graybosch, R.A., and C.J. Peterson. 2010. Genetic improvement in winter wheat yields in the Great Plains of North America, 1959-2008. Crop Sci. 50:1882-1890.

Jaggard, K.W., A. Qi, and E.S. Ober. 2010. Possible changes to arable crop yields by 2050. Philos. Trans. R. Soc. Lond. B Biol. Sci. 365:2835-2851.

Kolmer, J.A., Y. Jin, and D.L. Long. 2007. Wheat leaf and stem rust in the United States. Aust. J. Agric. Res. 58:631-638.

Lobell, D.B., W. Schlenker, and J. Costa-Roberts. 2011. Climate 
trends and global crop production since 1980. Science. doi:10.1126/science.1204531.

Morgan, J.A., J.D. Derner, D.G. Milchunas, and E. Pendall. 2008. Management implications of global change for Great Plains rangelands. Rangelands 30:18-22.

Peterson, C.J. 1992. Similarities among test sites based on variety performance in the hard red winter wheat region. Crop Sci. 32:907-912.

Peterson, C.J., V.A. Johnson, J.W. Schmidt, and R.F. Mumm. 1989. Genetic improvement and variability in wheat yields in the Great Plains. p. 175-184. In J.R. Anderson and P.B.R. Hazell (ed.) Variability in grain yields: Implications for agricultural research and policy in developing countries. Johns Hopkins Univ. Press, Baltimore, MD.

Rask, K.J., and N. Rask. 2011. Economic development and food production-consumption balance: A growing global challenge. Food Policy 36:186-196.

Reitz, L., and E.G. Heyne. 1944. Wheat planting and wheat improvement in Kansas. 33rd Biennial Report. Kansas State Board of Agriculture, Topeka, KS.
SAS Institute. 2008. The SAS system for Windows, release 9.2. SAS Inst., Cary, NC.

Schneider, U.A., P. Havlík, E. Schmid, H. Valin, A. Mosnier, M. Obersteiner, H. Böttcher, R. Skalský, J. Balkovič, T. Sauer, and S. Fritz. 2011. Impacts of population growth, economic development, and technical change on global food production and consumption. Agric. Syst. 104:204-215.

Systat Software. 2010. SigmaPlot for Windows, version 11.0. Available at http://www.systat.com (verified 5 Dec. 2011). Systat Software, Inc., Chicago, IL.

USDA. 2011. Hard winter wheat regional nurseries. Available at http://www.ars.usda.gov/Research/docs.htm?docid=11932 (verified 25 Nov. 2011). USDA, Washington, DC.

USDA National Agricultural Statistics Service. 2011. Data and Statistics. Available at http://www.nass.usda.gov/Data_and_ Statistics/ (verified 5 Dec. 2011. National Agricultural Statistics Service, Washington, DC.

Vogel, K.P., M. Schmer, and R.B. Mitchell. 2005. Plant adaptation regions: Ecological and climatic classification of plant materials. Rangeland Ecol. Manag. 58:315-319. 